\title{
CHINA'S STRATEGIC CHOICE: OPPORTUNITIES AND CHALLENGES
}

\author{
ARFAN MAHMOOD ${ }^{1}$, ZAHEER ABBAS ${ }^{2}$ \& DR. WEI HONG ${ }^{3}$ \\ ${ }^{1,3}$ School of Politics and International Studies, Central China Normal University, Wuhan, China \\ ${ }^{2}$ School of Political Science \& Public Administration, Shandong University, Jinan, China
}

\begin{abstract}
South Asian region is quite unique as it is inhabited by two nuclear powers hostile to each other and one of the emerging economies of the world. During Cold War, the strategic scenario in South Asia was pentagonal. The local powers were Pakistan and India while the external powers were the US, Soviet Union, and China. With the disintegration of Soviet Union, the subcontinent became a playground of four players which are still playing a crucial role in the regional politics of South Asia. The interplay of their national interests significantly affected the nature and form of China-India-Pakistan triangle. This study examines China's strategic choice for South Asia from Pakistan and India by making comparative analysis of both opportunities and challenges posed by them to China. It takes regional and global aspect of strategy into considerations while making a research over China's choice for strategic partner.

KEYWORDS: South Asia, China's Strategic Choice, Opportunities and Challenges \& Comparative Analysis
\end{abstract}

Received: Jun 02 2017, Accepted: Jul 05 2017, Published: Aug 05 2017, Paper Id: IJPSLIRAUG20175

\section{INTRODUCTION}

In the changing regional and global politics, South Asia has been gaining significance for China partly because of its economic potential and its strategic significance and partly because of China's tense even conflicting relations with countries in South and East China Sea. South Asian countries particularly Pakistan and India are of much importance for China in its regional and global strategy. China-India-Pakistan nexus plays a crucial role in regional politics of South Asia where rivalry has been referred as "the inner core of the HimalayanSouth Asian-Indian Ocean region” by Ashok Kapur. (Kapur, 2011)

During Cold War, South Asia's strategic scenario was pentagonal. (Cohan, 1983) India and Pakistan were the local powers while the external powers were the US, Soviet Union, and China. Their interactions and relations were greatly influenced by the "push-pull" factor. (Thornton, 1986) With the disintegration of Soviet Union, the subcontinent became a playground of four players which are still playing a crucial role in the regional politics of South Asia. The interplay of their national interests significantly affected the nature and form of China-IndiaPakistan triangle.

Chinese foreign policy towards South Asia evolved in 1990s as it made adjustments to the post-Cold War scenario, particularly to the changing dynamics of US-Pakistan ties and economic growth of India. Zhang Li, talking about Chinese interests in South Asia, posits that Beijing's stakes in China-India-Pakistan nexus are; to prevent any major armed conflict, to maintain friendly ties with both Pakistan and India and to avoid 'side-taking', to prevent any regional strategic alliance that harms the interests of China, to promote China as a "credible partner', and to secure its strategic and economic interests in the Indian Ocean by forming strong ties with the 
littoral states like Pakistan, India, Bangladesh, Sri Lanka and Myanmar (Burma). (Li, 2009) China's regional policy towards South Asia also aims at keeping the US influence at bay and making sure that Chinese economic and security interests are not threatened by Indian ambitions. South Asia, particularly Pakistan and India, has become a focus of regional strategy of China as it has been made clear by President Xi Jinping's recent visit to South Asia.

While talking about China's bilateral ties with Pakistan and India, it has a trusty relationship with Pakistan which is pronounced as "All Weather Friendship", but it has a tense, if not inimical, relationship with India. This triangular relationship is not free from US influence. So, it is imperative to study US factor in this triangular relationship. Although historical background of relationship cannot be taken as granted for state's future behavior as there are no permanent friends or enemies and what is permanent is national interest, but the element of trust is also very important for studying international relations as it leaves no room for a state to doubt the intentions of its partner.

Moving forward, which country is China's strategic choice in its policy towards South Asia in the near future; India or Pakistan will be analyzed by comparative study of opportunities and challenges. Areas of cooperation and conflict between their bilateral relationships will be investigated for rationalizing the nature of their future ties. The global and regional aspect of strategy will be taken into consideration while making a research over China's choice for strategic partner. The comparative case study method will be employed to make the research more rational and compact.

\section{OPPORTUNITIES AND CHALLENGES: COMPARATIVE ANALYSIS}

\section{Opportunities}

South Asia has been gaining significance for China owing to its strained relations with the countries in both South and East China Sea. In the regional and global strategy of China, South Asian countries especially Pakistan and China have great importance. Historically, China's relations with both Pakistan and India remained quite different. China and Pakistan enjoyed strong friendly relations since the initiation of their diplomatic ties while India-China relations present a mixed story of cooperation and conflict. The changing role and influence of both Pakistan and India in regional and international politics leaves China with opportunities and challenges to design its foreign policies towards Pakistan and India. The comparative study of both opportunities and challenges will be presented to analyze China's strategic choice in the near future.

\section{China-Pakistan Case Study}

Pakistan and China have a long history of strong bilateral relationship and the areas of cooperation between them have been re-prioritized in the last decade. The ambassador of China in Pakistan emphasized the strategic significance of Pakistan for China in 2012 as "the fulcrum of Asia." After 9/11, China started taking more interest in internal security of Pakistan and deepened security cooperation between them. Since 2001, Uighur separatist movement in Xinjiang has become the top agenda of cooperation. Keeping in view Pakistan's energy crisis, China also provides Pakistan with nuclear reactor for civilian nuclear energy use. In return, Pakistan does not challenge the core interests of China including Xinjiang, Taiwan, Tibet etc. and it is welcomed by the Chinese for this loyalty.

\section{Counter-Terrorism in Xinjiang}

The sources of competition and cooperation among the four actors (China, India, Pakistan and USA) in South Asia revolve around controlling the wave of militancy, securing and opening the routes of energy supply and trade and 
transport. Talking about the major concern of foreign policy of China, Pakistan occupies a central position in securing one of its core national interests: Xinjiang's stability. Recognizing the efforts of Pakistan in War against Terrorism, Ma Zhaoxu, spokesperson of foreign ministry of China, said that: "Pakistan is at the important forefront in the international counter-terrorism campaign and has made outstanding contributions in combating terrorism. China and Pakistan are friendly neighbors and have conducted sound cooperation in the field of counter- terrorism.” (Zhaoxu, 2011)

China intends to maintain a positive image in the Muslim world and for that it has sought Pakistan's support for managing the wave of militancy in Xinjiang after 9/11. Twenty-two Uighur, suspecting to carry out terrorist activity, were captured while crossing the border by Pakistani forces in 2002 and subsequent assassination of Hasan Mahsum, leader of East Turkistan Islamic Movement, by Pakistan are examples of cooperation to curb the menace of militancy in Xinjiang.

Militancy is a common problem of both China and Pakistan and this issue has given a new meaning to PakistanChina strategic ties. China recognizes that Pakistan has been playing a bigger role than India in fighting against terrorism. China believes that Uighur separatist movement and ethnic strife in western Xinjiang is a major hurdle in developing its western regions. China, in order to eliminate this menace of terrorism, is working with Pakistan and this cooperation will grow stronger in the future as it became clear from the agenda of recent Pakistan's Prime Minister's visit to China.

\section{Security Cooperation}

Pakistan-China relationship is founded on the security or defense cooperation. Chinese policy-makers believe that the stability of Pakistan ensures the stability in China's western regions. Military-to-military ties often symbolize the strength of relationship between the countries. Pakistan-China relationship, in the very start, was basically defense cooperation and from than onward military-to-military ties have been getting strong. China's objective behind enhancing military-to-military ties is to make sure that Pakistan facilitates, not hinders, the domestic stability in the borders of China, particularly in western Xinjiang. Military cooperation between Pakistan and China revolves around weapon's supply, sharing of intelligence, joint military exercises and counter-terrorism. For every two years, Pakistan and China have been conducting joint military exercises for long and in 2011; two armies conducted joint military exercises which aimed at building of capacity and sharing of intelligence for countering terrorism. Stronger military cooperation helps China to withstand the instability that erupts from the weak democratic governments in Pakistan. Although Pakistan cannot provide China with equipment or technology but the joint production can help China not only to skirt embargos but also provide cost-effective mechanism of enhancing country's military capabilities.

China also helped Pakistan in building its nuclear programmed and signed a civil nuclear agreement with Pakistan in 1986 and provided Pakistan with two civil nuclear power plants; Chashma I and Chashma II. In Pakistan's Prime Minister recent visit to China, they signed more than two dozen agreements including nuclear energy. Although militaryto-military cooperation heavily favors China, Pakistan gets a kind of support from China in the form of supporting remarks regarding Pakistan's fight against terrorism, a support which Pakistan lacks from international community. This support can be illustrated by Jiang Yu's statement after the killing of Osama Bin Laden on Pakistani soil: "China will continue staunchly supporting Pakistan developing and implementing its own anti-terror strategy based on its own national conditions.” (Buckley, 2011)

\section{Economic Cooperation}

Although Pak-China trade volume is very low as compared to China-India, but Pakistan's geostrategic location 
offers huge benefits to China in terms of economy and defense. China and Pakistan has free trade agreements. Firstly, economic ties between them are based on economic development to make Pakistan stable because the stability in Pakistan ensures the stability in Xinjiang. Secondly, geostrategic location provides China with access to crucial maritime routes for securing energy supplies of China through Strait of Hormuz and Persian Gulf. It also helps China to diversify its energy routes by containing the influence of US and India in the Indian Ocean and South China Sea. Economic cooperation over Gwadar Port provides China with a listening post to check Indian and US ambition as the observers from India, US and Japan became more apprehensive of China's maritime ambitions.

The recently concluded CPEC is the extension of China's 21st century Silk Road initiative to firm up its connectivity with Europe, Central Asia, and Africa via networks of highways, ports, and pipelines. Highlighting the significance of this mega project, First post reported, "this is the biggest overseas investment by China announced yet and the corridor is expected to be operational within three years and will be a strategic game changer in the region, which would go a long way in making Pakistan a richer and stronger entity than ever before." (Fazil, 2015) Both China and Pakistan cherish hopes that Pakistan would be turned into an economic hub through this massive investment plan and it would also help cementing Pak-China ties stronger. Emphasizing the importance of Pak-China bilateral relationship, the Guardian states that "the Chinese are not just offering to build much-needed infrastructure but also make Pakistan a key partner in its grand economic and strategic ambitions." (Qureshi, 2015) New trade routes will be opened for western China by this project and it would help providing direct access to China to energy-rich Middle East. This project would help China to solve its Malacca dilemma as well.

Most of Chinese investments are aimed at public sector in Pakistan where government is involved. These investments are concentrated on defense, nuclear energy, space programmes, electronic products, telecommunication and transportation etc. An agreement over the upgradation of Karakorum Highway which connects China's western regions to Pakistan is meant to ease commercial exchanges and the further integration of the two economies. Pakistan has been expecting Chinese investments to grow in private sector as well to rehabilitate the economy of Pakistan.

Gwadar port project is not only a symbol of China-Pakistan friendship, but also a key step of Chinese regional energy policy. It is at the mouth of the Persian Gulf and $400 \mathrm{~km}$ away from Strait of Hormuz, through which almost half of the world's oil passes. This port has immense economic and defense opportunities to offer to China and this project is a win-win situation for both Pakistan and China. It provides China with a lot of economic as well as security-related opportunities. China has also been investing in two other major joint mining projects at Saindak and Duddar.

\section{China-India Case Study}

India's status of rising power has left China with a number of opportunities and challenges both regionally and globally. Talking about the opportunities or areas of cooperation between them, there are some areas where they have worked together to a fair degree. Regionally, the size of Indian market offers big temptation to China to benefit from and they have cooperated in this field with good degree of success and in 2008, India became the largest trading partner of China. But consistently rising trade imbalance between them has been a continuous source of tension in Indian circles.

Talks of border dispute, one of the most sensitive issues between them, have shown little sign of success as they have taken some steps to enhance confidence building measures between them by establishing 'hotline' between their field commanders and an agreement over conducting joint military exercises. But still they are far from developing a consensus 
for the resolution of long-existing border dispute between them.

Globally, on the environmental and international financial system front, they have coordinated their efforts successfully. Since 1992 Rio Summit, environmental degradation has been the battleground between developing and developed world. Both of them put the blame of environmental degradation and global warming on each other. China, the largest greenhouse gasses' emitter into the atmosphere, claims that developed world has major share in the environmental degradation in the past and they alone are responsible for that and they should be legally binding to reduce greenhouse gas emission and developing countries should have voluntary commitment in this regard. India supported China as it is in the common interest of both of them to avoid binding commitments regarding greenhouse gas emission. The US also refuses to accept legally binding commitment unless and until China accepts the same.

On the international economic system front, both China and India have coordinated their stance successfully. Now both of them are members of G 20 and the economic power has shifted from G 7 to G 20 especially after 2008 economic recession and recognizing both China and India's role in international economy, in Pittsburgh Summit high percentage of quota of IMF's fund was shifted to developing world. Over the WTO's negotiations in Doha Round, both China and India coordinated their stance on several issues.

\section{Challenges}

The changing dynamics of regional and global politics and China's changing policy of "Single-dimensional" and "Limited" relations to "Multiple-dimensional" and "Comprehensive" relations to South Asian countries is not free from challenges. The comparative study of both opportunities and challenges in the China-India-Pakistan nexus will help us to test our research hypothesis.

\section{China-Pakistan Case Study}

Pak-China ties, reinforced by the rhetoric, are not free from challenges. In the current scenario, Pak-China alliance is facing the following challenges: First, the financial support which Pakistan expects to get from China is not as readily available as it used to be. Secondly, in order to balance support to its ally, China finds more difficult to extend its support to Pakistan as it becomes more unstable especially over the spreading of Islamic militancy and security of nuclear weapons. Finally, South Asian regional dynamics and structures of bilateral alliance mean that the narrative of their bilateral relationship is required to be carefully balanced with their strategic interests and rivalries.

\section{China: A Different Kind of Investor}

During and after the Cold War, Pakistan extensively relied on 'bail-outs' by its allies. After 9/11, Pakistan assumed a great strategic role once again as non-NATO US ally in US War against Terrorism. At the end of Musharraf era, it became clear that to secure bail-outs at least from China would no longer be an easy task and it became crystal clear when President Asif Ali Zardari in 2008 paid an official visit to China and at that time Pakistan was about to default, but China did not bail it out and eventually Pakistan had to knock IMF door for a line of credit.

The amount of financial assistance, in terms of grants and aid, provided to Pakistan by China did not match the other countries like US. US in the name of economic and military aid has been providing Pakistan with US\$ 2 billion on average per year since 2001 and China's volume of cumulative assistance to Pakistan from 2004 to 2009 totaled just US\$ 217 million and it was mostly driven by disaster relief. The existing model of assistance from China is being expected to 
meet the kind of support Pakistan needs from China. Although China's assistance remains low as compared to the US but it is mostly free from conditions unlike the US. Emphasizing the significance of China's timely assistance in 2010 and 2011 to manage the issue of flood affecters, Masod Khan, Pakistan's ambassador to China, stated that: China provided Pakistan with generous, timely and unconditional relief." Although China may provide unconditional assistance to Pakistan but it will not give a blank check to Pakistan either.

\section{Pakistan: A Risky Ally for China}

The geographical location of Pakistan is of vital importance to China. But there are some areas in the economic and security cooperation that demonstrate the limitations regarding political good will between them. A stable Pakistan best serves China's security interests in western Xingjian but Pakistan's deteriorating security condition has put a question mark on Islamabad's own capacity in protecting Beijing's interests in Xinjiang and Chinese investments in Pakistan. However, for protecting Chinese workers and interests in Pakistan, a joint task force was set up in 2007. Owing to growing security risks, China has become hesitant to invest in Pakistan despite the fact that Pakistan is convincing China to invest heavily in Pakistan. China's concern over running the Gwadar Port is because of security risks in Baluchistan. However, realization of the full potential of Gwadar will ultimately depend on government of Pakistan to stabilize Baluchistan. (Wirsing, 2012)

For delivering on security situation, China emphasize on Pakistan's military rather than civilian government. The fact is the military of Pakistan will not only depend on China for technology, hardware and intelligence sharing but also on US military support because it dominates that market. The military of Pakistan has benefitted more from its relationship with Pentagon than Beijing for hardware, technology and intelligence. So, Pakistan's military will not cause irreparable damage to Pak-US military-to-military ties.

Aware of China's rising influence in world affairs, Pakistan is in constant need of support from China in multilateral organizations. But as far as Shanghai Cooperation Organization's membership is concerned, it is not a story of "brothers sharing weal and woe." (Weitz, 2012) Both Pakistan and India has observer status of SCO and in 2012 when China had the presidency status and even Russia gave its assent for the admission of both India and Pakistan into SCO as its permanent members, they were not admitted and still their membership is pending. It is another example of Pakistan's domestic security dilemma hindering its capability to position itself in regional organizations.

The government of Pakistan is acutely aware of securing and managing Chinese interests and it has been reflected in the value it places on the strategic ties through rhetoric and exchange of high profile of civilian and military trips. Pakistan's military operation "Zarb-e-Azab" against militants has been quite successful so far and even the US has accepted that the terrorist's activities of Haqani network in Afghanistan has been reduced owing to Pakistan's military action against militants.

\section{China-India Case Study}

\section{Border Disputes}

China-India relations are characterized by border disputes which have led them to three Sino-Indian war in 1962, Chola incident in 1967, and Border Skirmish in 1987. Border dispute, one of the most sensitive issues between them, has been considered a major irritant in the Indo-China bilateral relations. The border dispute revolves around sovereignty over Tibet and Arunacahl Pradesh as it is linked to their security and considered a matter of prestige. China claims sovereignty 
over Tibet and the whole of Arunachal Pradesh, an Indian state, as part of southern Tibet. China's occupation or sovereignty claim over Tibet was acquiesced by Nehru government in 1954 under Panchaseel Agreement but India failed to get recognition of Macmohan Line as a border line between them in the east from China.

From than onwards, border issue remained a bone of contention between them. Although some positive and peace inspiring efforts were made in the direction of resolving that issue like the agreements over "the Maintenance of Peace and Tranquility along the Line of Actual Control in the India-China border areas" and "Confidence-Building Measures in the Military Relations” in 1993 and 1996 respectively, but still they are far from developing a consensus to resolve the border issue. After the conclusion of these two agreements, it was logical to hope that it would result into demobilization of troops and decrease in war-making efforts along the Line of Actual Control (LAC) but it did not happen. Quite contrary to that, they started building military capabilities along the border which triggered arms race between them. Border skirmishes and tensions have not stopped completely. In the face of mutual mistrust and suspicion, to resolve border issue remains one of the biggest challenges to overcome which has still been plaguing their relationship.

\section{China's Maritime Ambitions}

India has been seriously concerned about China's maritime ambitions in the Indian Ocean which India considers its area of influence. Both of them are net importer of energy products and are concerned about the safe and smooth passage for the delivery of their vital imports through Indian Ocean. More than $85 \%$ imports of China passes from Malacca' Strait where India has strong presence while India's substantial amount of imports passes from Gwadar Port where China is heavily investing.

China's financial and technical support to build a chain of ports; Gwadar Port of Baluchistan, Hambantota Port of Sri Lanka, Chittagong Port of Bangladesh and Port and Communication facilities at Myanmar (Burma) has been perceived as threat by India and even by the US to their interests in the Indian Ocean. But China has repeatedly denied the strategy of 'string of pearls', a western term for China's maritime ambitions. Suspecting the strategy to 'encircle' India, India, along with the US and Japan, is very much conscious to deter the encirclement of India by China. To buttress its 'Malaccan Strategy', India is enhancing its military and naval presence in Andaman and Nicobar islands. Talking about 'India's 15 year Defense Plan', the focus is China, not Pakistan.

The growing competition to secure access to more and more energy resources, for instance, Central Asia and Africa, is another challenge to meet. Both of them are net importer of energy and there is tough competition going on between them in Central Asia and Africa to meet their industrial requirements. Keeping in view their mutual mistrust and suspicion, the possibility of shifting this energy competition, although less than border disputes, but cannot be ruled-out altogether.

\section{Nuclear Issue}

Nuclear issue between India and China has been a persistent challenge in their bilateral relationship. India's nuclear programmed is aimed to deter threats both from China and Pakistan, while China's programmed was meant to deter Russian threat initially, but now China seems rather more concerned about US-India growing strategic ties. India, Pakistan and Israel are non-signatory of NPT and CTBT, the agreements which are considered by many as tool of nonproliferation. Considering these NPT and CTBT as unequal and discriminatory, India dubs these treaties as P-5 (Permanent members of Security Council) are not covered by these treaties. China signed the NPT and CTBT in 1993 and 1996 
respectively only after realizing that it's nuclear programmed was effective deterrence against its opponents. (Pratibha, 2009)

Keeping in view the non-recognition of Indian nuclear capability by China, India is working to enhance or further develop its delivery system. Believing that only credible nuclear deterrence of India may compel China to bring to negotiation table with India, India has not signed the NPT and CTBT. So, to foster deep friendly relationship between them, nuclear issue is one of the major challenges to overcome yet.

\section{Terrorism}

On the front of counter-terrorism, although China and India decided to fight this menace collectively but there are differences between them. In countering regional terrorism, there are sharp differences between them over terrorism policy. I.e. for China, managing of terrorists is priority for East Turkistan element and for India, terrorists are gunmen or suicide bombers infiltrating cross the Line of Control (LOC) in Kashmir. Both of them did not have a common enemy, so their counter-terrorism basically was without important fruit. But now cooperation between them is enhancing in this field because China has started taking neutral stance over Kashmir problem between India and Pakistan for the last many years. India and the US share similar stance to dub Pakistan as the "epicenter" of transnational terrorism. India still is very much apprehensive of Pakistan-China close cooperation and China's support of Pakistan in fighting terrorism as foreign minister spokeswoman, Jiang Yu, stated: "China will continue staunchly supporting Pakistan developing and implementing its own anti-terror strategy based on its own national conditions”. (Buckley, 2011)

\section{CONCLUSIONS}

The historical analysis of tetragonal relationship of the US-Pakistan-China-India nexus, the evolving policy of China towards Pakistan, the limitations of Pakistan to deliver on the regional interests of China, and reluctance of China to jeopardize its bilateral relationship with the US and India in the region describes the assertion why China is not able to act for Pakistan as the US replacement is both a deeply problematic and unlikely proposition. China is also not able to leave Pakistan as it is integral to its security of western regions and plays a crucial role in China's regional policy towards South Asia owing to its geo-strategic significance. The strategic relationship, illustrated by officials, rests on mutually beneficial relationship based on respect and "multi-dimensional cooperation, and in the security circles of both countries it has been justified by the perceived regional ambitions of both the US and India. In its long-term policy towards Pakistan, China would wish to be a predominant influence and strategic partner of Pakistan. The bond between them is strategic, and it is grounded in military ties and in future like past the agenda will be driven by China, although cooperation in many areas has been established on the request of Pakistan.

China-India relationship is a mixture of stalemate and progress. Most of the history of their relationship is characterized by border disputes and mutual mistrust and suspicion, but there is understanding and cooperation on several issues between them and again few problems defy solution. Both are countries with huge territory and population and huge potentials. Both are rising power, destined to play a big role unfolding world order. There will be enough space for both to cooperate, but mutual mistrust, suspicion and ambition invites rivalry.

After having comparative analysis of opportunities and challenges, China's regional policy interests towards South Asia, and current state of affairs of South Asian politics, and the persistent element of mutual mistrust and skepticism regarding each other's intentions or ambitions between China and India, it seems that, although China and India 
are destined to play bigger role in global politics and have expressed their desire to cooperate to make this century an 'Asian Century' but the competition to assume regional leadership seems to be a fact of life, Pakistan will retain its significance as a strategic partner of China in near future. China will keep China-Pakistan strategic partnership as a cornerstone and compete with India in cooperation in near future.

\section{REFERENCES}

1. Buckley, C. (2011). China Hails Death of Bin Laden, Defends Partner Pakistan. Washington DC: Reuters.

2. Cohan, S. P. (1983). Geo-strategic Factors in India-Pakistan Relations. Washington D.C: Asian Affairs.

3. Fazil, Muhammad Diam. (2015). China-Pakistan Economic Corridor: Potential and Vulnerabilities. Islamabad: The Tribune Press.

4. Kahn, J. (2009). Why India Fears China. New York: Newsweek.

5. Kapur, A. (2011). India and the South Asian Strategic Triangle. UK: Routledge.

6. Kardon, I. (2011). China and Pakistan: Emerging Strains in the Entente Cordiale.

7. Li, Z. (2009). To manage conflict in South Asia: China's Stakes, Perceptions and Inputs. Beeijing: Asia Paper: Institute for Security and Development Policy.

8. Pratibha, M. S. (2009). Front Recluse to Participant: China in Nuclear Arms Control Regime. New Delhi: World Focus.

9. Qureshi, Irfan. (2015). Challenges Posed by China-Pakistan Economic Corridor. Islamabad: The Express Tribune.

10. Thornton, T. P. (1986). The Challenge to US Policy in the Third World. Boulder: Westview Press.

11. Thottam, J. (2009). A Rivalry on the Roof of the World. New York: Times.

12. Weitz, R. (2012). China-Russia's Anti-NATO. Beijing: The Diplomat.

13. Wirsing, R. (2012). Baloch Nationalism and the Geopolitice of Energy Resources. Washington DC. 
